\section{GAMBARAN TINGKAT PENGETAHUAN TENTANG PENANGANAN PERTAMA HIPOTERMIA PADA UNIT KEGIATAN MAHASISWA PECINTA ALAM (UKM MAPALA)}

Rizki Vauzy Firmansyah¹, Ida Herdiani² ${ }^{2}$ Ida Rosidawati

123 Universitas Muhammadiyah Tasikmalaya

Article Information

Received: January

Revised: February

Available online: July

Keywords

First treatment of hypothermia, knowledge, student activity unit nature lovers

Correspondence

Phone: (+62)8159262734

E-mail: idaherdiani17@gmail.com

\section{ABSTRACT}

Tercatat pada tahun 2006 hingga tahun 2019 terdapat beberapa kejadian kematian akibat hipotermia. Mapala adalah sebuah organisasi yang beranggotakan mahasiswa dan memiliki kesamaan minat dan kepedulian terhadap alam liar, yang obe di antaranya dalam pendakian gunung lebih dari 3000 mdpl, sehingga UKM terancam hipotermia saat melakukan aktivitas alam di pegunungan. Oleh karena itu diperlukan pengetahuan yang cukup dalam penanganan pertama korban hipotermia. Penelitian ini bertujuan untuk mengetahui tingkat pengetahuan tentang pengobatan pertama hipotermia pada mahasiswa pecinta natutal (Mapala) di kota tasikmalaya. Metode penelitian yang digunakan adalah deskriptif kuantitatif dengan jumlah sampel 43 orang menggunakan tehnik simple stratified random sampling. Pengumpulan data menggunakan kuesioner, analisis data secara univariat yaitu distribusi frekuensi. Hasil penelitian menunjukkan bahwa pengetahuan responden terbanyak sebanyak 33 orang $(76,7 \%)$, baik 4 orang $(9,3 \%)$ maupun kurang 6 (14,0\%). Berdasarkan hasil penelitian diharapkan profesi keperawatan meningkatkan kualitas perawat dengan memberikan edukasi dan pengetahuan kepada masyarakat awam dan pecinta alam (Mapala) tentang penanganan pertama hipotermia yaitu deskriftif kuantitatif.

Kata kunci : Hlpotermia, Mapala, Penanganan Pertama, Pengetahuan

PENDAHULUAN

Indonesia dikenal sebagai surga bagi tumbuhnya gunung berapi. Direktorat Vulkanologi dan Sumber Daya Mineral mencatat sedikitnya terdapat 127 gunung berapi yang berbaris sepanjang $7000 \mathrm{~km}$ membentang dari Aceh melewati seluruh Pulau Sumatra - Jawa - Bali - Lombok dan Sumbawa (NTB) Flores (NTT) serta di kepulauan lainya di Provinsi Maluku Utara hingga berakhir di Sulawesi Utara. (Abdillah, 2017) Ketinggian di atas 3100 Mdpl terlepas dari perubahan terus menerus dari kondisi cuaca ekstrim, juga menyembunyikan bahaya hipoksia. Manusia pada ketinggian ini sangat dekat dengan batas toleransi untuk hipoksia. Hal tersebut menimbulkan penurunan konsentrasi oksigen di darah, sehingga menurunkan tekanan oksigen
(PaCO2). Penurunan konsentrasi oksigen menyebabkan sel mengalami gangguan dalam melakukan metabolisme dan memproduksi panas. Ketidakseimbangan antara produksi panas dengan panas yang dikeluarkan dapat meningkatkan resiko hipotermia (Kipreos, 2012) Hipotermi atau hypothermia merupakan suatu kondisi dimana tubuh kehilangan suhu panas dengan cepat sehingga menyebabkan temperatur tubuh menurun drastis. Seseorang bisa dikatakan mengalami hipotermia jika suhu tubuhnya di bawah $35^{\circ} \mathrm{C}$. Hipotermia sangat berbahaya karena dapat berkembang dengan cepat. Jika tidak diobati, dapat menyebabkan syok dan berakibat fatal. Kemudian cuaca merupakan salah satu faktor penyebab yang paling utama. Lingkungan yang dingin termasuk temperatur udara maupun suhu 
rendah (atau keduanya), angin kencang, radiasi sinar matahari yang rendah, curah hujan yang tinggi, dapat meningkatkan koefisien perpindahan panas. (Milne, 2009) Resiko hipotermia dapat dilakukan dengan melakukan pertolongan pertama dengan cara yang tepat Adapun pertolongan pertama yang harus dilakukan ketika mengalami hipotermia adalah kenali terlebih dahulu Hazard dan resiko yang akan di timbulkan oleh Hazard tersebut. Hazard adalah sesuatu yang potensial menimbulkan kerugian, misalnya : suhu dingin, hujan, lapar, sepatu jebol, ranting yang rapuh, jurang, tebing dan usia. Kemudian Resiko adalah cedera, penyakit atau bahkan kematian yang ditimbulkan oleh Hazard. Adapun yang harus dilakukan selanjutnya adalah mengganti baju basah dengan yang kering agar hipotermia tidak semakin buruk. Kemudian Hangatkan dengan cara menghindari angin, buat tempat berlindung, selimuti dengan emergency blanket, sleeping bag, setalah itu berikan asupan Nutrisi jika sadar, berikan minuman hangat Pastikan jalan napas tetep terbuka (Lelitasari , 2014) Penangan pertama hipotermia ini apabila tidak dilakukan maka akan menyebabkan terjadinya komplikasi, bahkan kematian. Komplikasi yang dapat muncul adalah Frostbite, yaitu cedera pada kulit dan jaringan di bawahnya karena membeku, Chilblains yaitu peradangan pembuluh darah kecil dan saraf pada kulit.Trench foot, yaitu rusaknya pembuluh darah dan saraf pada kaki akibat terlalu lama terendam air, Gangrene atau kerusakan jaringan (Willy, 2019), Oleh karena itu, perlu adanya pembinaan kepada masyarakat awam atau kepada mahasiswa melalui unit kegiatan mahasiswa yang berfokus pada mahaiswa pecinta alam (mapala) yang beresiko ketika melakukan kegiatan alam bebas pendakian gunung lebih dari 3000 Mdpl. Mapala merupakan Organisasi yang beranggotakan para mahasiswa yang mmpunyai kesamaan minat serta kepedulian terhadap alam bebas yaitu salah satunya adalah pendakian gunung lebih dari 3000 Mdpl (Papilaya dkk, 2016) dengan demikian bahwa UKM Mapala ini beresiko tinggi akan terkenanya hipotermia saat melakukan kegiatan alam di pegunungan. Oleh karena itu, dibutuhkan pengetahuan yang cukup dalam penanganan pertama pada korban hipotermia. Sehingga penelitian ini bertujuan untuk memperoleh gambaran tingkat pengetahuan penanganan pertama hipotermia pada unit Kegiatan Mahasiswa Pecinta Alam (Mapala) di Kota Tasikmalaya.

\section{METODE PENELIITIAN}

Penelitian ini merupakan penelitian deskriptif kuantitatif. Besarnya sampel dalam penelitian ini 43 responden dengan menggunakan tehnik simple stratified random sampling. Tempat penelitian ini dilaksanakan di sekretariat Unit Kegiatan Mahasiswa Pecinta Alam (UKM Mapala) Kota Tasikmalaya. Data diperoleh menggunakan kuisioner yang sebelumnya telah diuji validitas dan reabilitas dengan jumalh soal valid dan reliabel sebanyak 26 soal. Analisis yang dilakukan adalah analisis univariat yaitu distribusi frekuensi.

\section{HASIL PENELITIAN}

Penelitian tentang gambaran tingkat pengetahuan tentang penanganan pertama hipotermia pada unit kegiatan mahasiswa pecintaalam (UKM MAPALA) di kota Tasikmalaya, Berikut hasil penelitian di bawah ini. A.Pengetahuan Mahasiswa Pecinta Alam tentang Hipotermia

1.Distribusi frekuensi responden berdasarkan

Total keseluruhan mahasiswa pecintaalam di Kota Tasikmalaya :

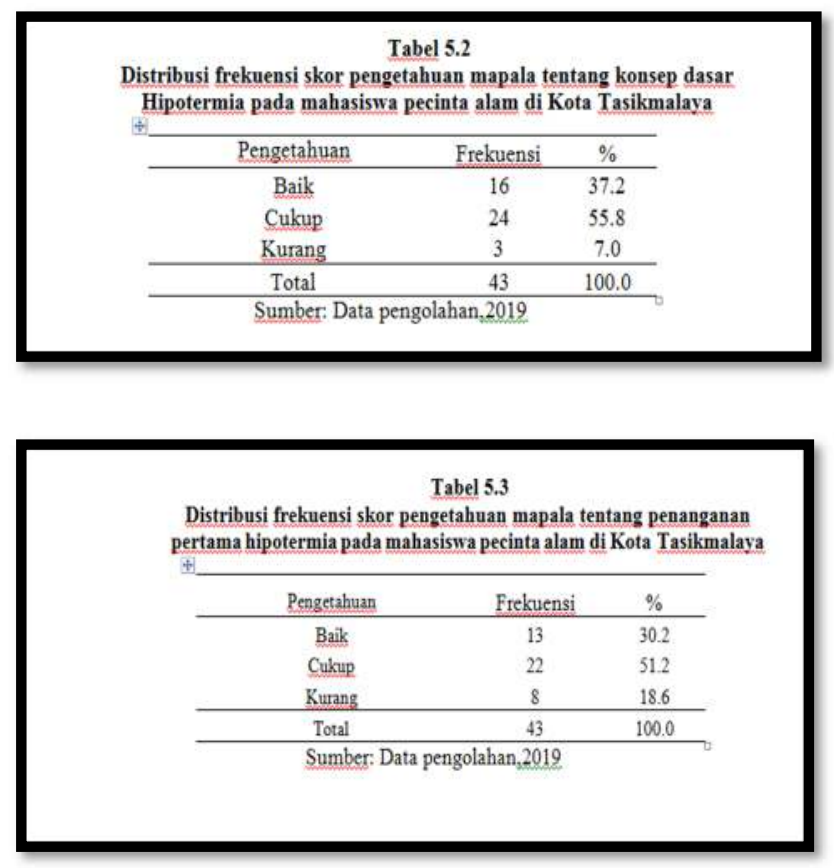




\section{PEMBAHASAN}

Berdasarkan hasil penelitian menunjukan bahwa responden mapala memiliki pengetahuan tentang penanganan pertama hipotermia dalam kategori baik berjumlah 4 orang (9,3\%), kemudian kategori cukup sebanyak 33 orang $(76,7 \%)$ dan kategorik kurang berjumlah 6 orang (14,0\%). Menurut asumsi peneliti, pengetahuan mapala dari 11 perguruan tinggi di Kota Tasikmalaya sebagian besar memiliki kategori yang cukup, kertidak samarataan informasi terkait pelatihan dasar dalam memahami penanganan pertama hipotermia pelatihan itu sendiri bisa meningkatkan kepada pengetahuan terkait penanganan hipotermia.

Hal ini sesuai dengn teori yang dikemukakan oleh Notoatmodjo, (2007) bahwa pengetahuan dapat diperoleh seseorang melalui apa yang dilihat, didengar ataupun yang dirasakan seseorang sehingga membentuk satu informasi yang dibenarkan oleh orang tersebut. Selain itu pengetahuan bisa didapat bila seseorang telah melakukan kontak atau pengamatan terhadap sesuatu pengalaman atau objek tertentu sehingga menimbulkan fakta yang dibenarkan oleh seseorang. Saling berkaitan antara proses pembelajaran yang di pengaruhi oleh berbagai faktor dari dalam seperti motivasi dan faktor luar seperti sarana informasi yang tersedia, serta keadaan sosial budaya. (Budiman, 2018; Falah, dkk. 2019)

Kemudian faktor yang menyebabkan bahwa kategori mahasiswa pecinta alam yang menunjukan bahwa cukup yaitu dari kurikulum yang memang tidak satu persepsi antara mapala yang satu dengan mapala yang lainnya, ini berimbas pada jenjang pelatihan dasar yang dilakukan oleh mapala tersebut akibat atau dampak yang terjadi sesuai fakta yang ada ini menjadikan pelatihan dasar di kalangan mapala ini menjadi tidak selaras atau tidak sama sehingga pengetahuan yang dimilikipun mempunyai pengetahuan yang berbeda beda serta kapasitas yang berbeda beda pula. Pentingnya pelatihan yang sesuai dengan standar oprasional (SOP) mampu menngembangkan organisasinya tersebut serta mahasiswa pecinta alam itu sendiri dalam meningkatkan kemampuan teori serta pengaplikasian dari praktek dalam pelatihan penanganan pertama hipotermia.

Hasil penelitian ini sesuai dengan penelitian Elfrianto (2016) sebelumnya yaitu pelatihan merupakan suatu perbaikan kinerja dan meningkatkan motivasi belajar yang dibebankan padanya, sehingga seseorang mengalami kemajuan dalam hal pengetahuan, keterampilan dan keahliannya sesuai dengan bidang yang dimilikinya. Pelatihan juga sering dipasangkan dengan pendidikan dasar yang ada. Peran perawat yang harus ada dalam hal ini adalah salah satunya dengan memberikan adanya pelatihan dasar seperti kegawatdaruratan yang mampu memotivasi mahasiswa pecinta alam di kota Tasikmalaya contoh kecilnya yaitu penanganan pertama pada hipotermia.

\section{KESIMPULAN DAN SARAN}

\section{A.Kesimpulan}

Gambaran pengetahuan tentang penanganan pertama hipotermia pada unit kegiatan mahasiswa pecinta alam (UKM MAPALA) di Kota Tasikmalaya sebagian besar sesuai dengan penelitian ini yaitu kategori Cukup. Peran perawat yang bisa meminimalisir resiko terjadinya hipotermia pada mahasiswa pecinta alam salah satunya adalah dengan cara memberikan edukasi, motivasi serta memberikan standar operasional prosedur dalam bidang kesehatan terutama penanganan pertama hipotermia, sehingga mahasiswa pecinta alam tidak khawatir dalam hal pedoman yang akan dikerjakan di latihan dasar yang menjadi salah satu syarat masuk ke organisasi ukm mapala.

\section{B. Saran}

Berdasarkan simpulan diatas, maka dapat disarankan : 1.Bagi Universitas Muhammadiyah Tasikmalaya

Hasil penelitian ini diharapkan dapat menjadi salah satu referensi bagi institusi guna menambah perbendaharaan literatur perpustakaan dan sebagai salah satu pengembangan ilmu pengetahuan dalam pelaksanaan catur darma perguruan tinggi.

2.Bagi Peneliti

Hasil penelitian ini diharapkan dapat menambah wawasan dan pengalaman dalam melakukan penelitian tentang penanganan pertama hipotermia guna mengembangkan ilmu pengetahuan.

3.Bagi Profesi Keperawatan

Hasil penelitian ini bias diterapkapka menjadi acuan bagi perawat bahwa mahasiswa pecinta alam harus tetap di pantau terkait standar oprasional procedure dalam hal penanganan pertama hipotermia mengingat bahwa kegiatan mapala ini sangat beresikot inggi mengalami kecelakaan apabila tidak ada pembinaan terlebih dahulu dari tenaga medis atau profesi perawat .

4.Bagi Unit Kegiatan Mahasiswa Pecinta Alam (UKM MAPALA)

Hasil penelitian ini bisa dijadikan bahan acuan atau evaluasi serta harus menjadikan hal utama dalam memiliki kemampuan serta keterampilan penanganan pertama hipotermia , mengingat bahwa legiatan kegiatan mapala sangat beresiko sekali, oleh karena itu perlu adanya pengetahuan yang mempuni dan handal ketika sudah siap menjadi anggota resmi mapala. 
5. Bagi Peneliti Selanjutnya

Hasi penelitian ini bias dijadikan referensi untuk penelitian selanjutnya untuk memenuhi criteria pengetahuan danpenanganan hipotermia, penelitian hipotermia dengan sikap dan mengevaluasi hasil dari penelitian ini.

\section{DAFTAR PUSTAKA}

Abdillah. (2017). Perancangan handbook "barisan raksasa api tanah jawa" sebagai media informasi dan edukasi. file:///C:/Users/live/Downloads/ 15.04.1356_bab1.pdf. Diakses pada tanggl 20 April 2019

Aziz, A. (2013). Konsep Dasar Keperawatan. Edisi 2. Jakarta: Salemba Medika

Badriah. (2006). Metodologi Penelitian Ilmu-IImu Kesehehatan.Bandung :Multazam

Bawono. (2017). Pengetahuan pendaki gunung tentang pertolongan pertama pada hipotermi di kawasan gunung lawu http://l C:/Users/live/Downloads Ljurnal\%2openelitian\%2ohipotermia/BAB\%201.pdf. Siakses pada tanggal 19 April 2019

Budiman, dkk.(2014).Kapita Selekta Kuesioner.Jakarta : Salemba Medika

Budiono, https://travel.detik.com/travel-news/d4368444/sepanjang-tahun-2018-gunung-semerudidaki-853-ribu-orang, diakses pada tanggal 19 april 2019.

dr.Lelitasari,MKK (2014). Pertolongan pertama pada pendakian. http: // www. gedepangrango.org/wpcontent/uploads/2014/12/pertolongan-pertamapada-pendakian.pdf. Diakses pada tanggal 19 April 2019.

Falah, M., Tai, C. Y., Lu, Y. Y., Liu, C. Y., \& Lismayanti, L. (2019). Tuberculosis Knowledge among University Students in Indonesia. South East Asia Nursing Research, 1(2), 95-106.

Iryani. (2013).Dlajah: Persiapan Naik Gunung. Bandung: Wanadri.

Brocherie, dkk. (2015). Emerging Environmental and Weather Challenges in Outdoor Sports. Switzerland : Institute of Sports Sciences. Diakses pada tanggal 20 april 2019

Kipreos, G. (2012). A Biological Super Athlete or a Product of the Sport Industry. Greece: International Journal of Sport Management Recreation \& Tourism. Diakses pada tanggal 20 April 2019

Mandiri, A. (2016). Pendaki Gunung Rinjani Berasal dari 60 Negara. www.suara.com. Diakses pada tanggal 18 april 2019
Milne, T(2009). Hypothermia: Avoid, Recognize and Treatment. www.wta. Diakses pada tanggal 20 Agustus 2019.

Notoatmodjo, S. (2010).Metodologi Penelitian Kesehatan.Jakarta : Rineka Cipta.

Sulistyaningsih.(2011).Metode Penelitian Kebidanan Kuantitatf -Kualitatif.Yogyakarta : Graha Ilmu.

Sujarweni, W. (2014). Metodologi Penelitian Keperawatan.Yogyakarta :GAVA MEDIA

Yandri N, dkk. (2018). Hubungan Pengetahuan Hipotermi dengan Perilaku Penanganan Awal Hipotermi pada Mahasiswa Pencinta Alam di Unswagati dan IAIN Syekh Nurjati Kota Cirebo. file: ///C: /Users /live/ Downloads/17164761-1-SM\%20(2).pdf. Diakses pada tanggal 19 April 2019 